\title{
PENGARUH CAR, NPL, DER DAN LAR TERHADAP ROA PADA BANK UMUM DI BURSA EFEK INDONESIA
}

\author{
Ayu Chintya Arie Zeuspita ${ }^{1}$ \\ I Putu Yadnya ${ }^{2}$ \\ ${ }^{12}$ Fakultas Ekonomi dan Bisnis Universitas Udayana (Unud), Bali - Indonesia \\ email: ayuchintya23@gmail.com
}

\begin{abstract}
ABSTRAK
ROA merupakan perbandingan antara laba sebelum pajak dengan total aset bank. Faktorfaktor yang dapat mempengaruhi ROA harus dicermati oleh pihak manajemen bank agar dapat memperoleh ROA yang optimal. ROA yang optimal menunjukkan bahwa bank mampu dengan baik memanfaatkan aset yang dimiliki untuk menghasilkan keuntungan. Tujuan dari penelitian ini adalah untuk mengetahui pengaruh CAR, NPL, DER dan LAR secara parsial terhadap ROA pada bank umum di BEI periode 2013-2015. Sampel pada penelitian ini adalah perusahaan perbankan yang terdaftar di Bursa Efek Indonesia periode 2013-2015 yang berjumlah 31 perusahaan perbankan, yang diambil menggunakan metode sensus. Pengumpulan data dilakukan dengan metode observasi nonpartisipan. Teknik analisis data yang digunakan adalah regresi linier berganda. Hasil penelitian memperlihatkan bahwa terdapat pengaruh positif signifikan antara CAR dengan ROA. NPL menunjukkan pengaruh negatif signifikan terhadap ROA. DER menunjukkan pengaruh negatif signifikan terhadap ROA, dan LAR menunjukkan pengaruh positif signifikan terhadap ROA.

Kata Kunci: CAR, NPL, DER, LAR, ROA
\end{abstract}

\begin{abstract}
ROA is a comparison between pre-tax profit and total bank assets. Factors that can influence ROA must be observed by bank management in order to obtain optimal ROA. Optimal ROA shows that banks are able to make good use of assets owned to generate profits. The purpose of this study was to determine the effect of CAR, NPL, DER and LAR partially on ROA in commercial banks on the IDX for the period 2013-2015. The sample in this study were banking companies listed on the Indonesia Stock Exchange for the period 2013-2015, which totaled 31 banking companies, which were taken using the census method. Data collection is done by nonparticipant observation methods. The data analysis technique used is multiple linear regression. The results showed that there was a significant positive effect between CAR and ROA. NPL shows a significant negative effect on ROA. DER shows a significant negative effect on ROA, and LAR shows a significant positive effect on ROA.
\end{abstract}

Keywords: CAR, NPL, DER, LAR, ROA 


\section{PENDAHULUAN}

Industri perbankan yang ada di Indonesia telah mengalami perkembangan yang pesat dari waktu ke waktu. Industri perbankan merupakan tulang punggung perekonomian negara (Wibowo, 2012). Bank adalah lembaga yang mempunyai peran sebagai perantara dalam bidang keuangan antara pihak yang mempunyai dana dengan pihak yang membutuhkan dana. Sebagian besar masyarakat mempercayakan uang dan dana yang dimiliki kepada bank. Selain itu, masyarakat yang membutuhkan dana juga cenderung akan meminjam kekurangannya di bank. Oleh karena itu, bank memiliki peranan yang sangat penting dalam kaitannya dengan perekonomian masyarakat. Masalah ataupun kegagalan yang kemungkinan terjadi di bank akan sangat meresahkan masyarakat. Menjaga kesehatan dan kelangsungan kinerja perbankan merupakan hal yang wajib dilakukan mengingat bank sebagai lembaga yang menghimpun dana masyarakat. Dampak negatif yang akan dirasakan nasabah yang menginvestasikan dananya, apabila bank mengalami kegagalan dalam menjalankan usahanya. Bank juga akan kehilangan kepercayaan dari nasabahnya dan menyebabkan nasabah tidak bersedia lagi menginvestasikan atau menyimpan dananya di bank.

Perbankan sebagai badan usaha yang bergerak di bidang keuangan atau finansial sangat membutuhkan kepercayaan dari para nasabah guna mendukung dan memperlancar kegiatan yang dilakukannya (Sukarno \& Syaichu, 2006). Tingkat kesehatan bank harus dipelihara agar kepercayaan masyarakat pada bank tetap terjaga dan usaha yang dijalankan bank dapat berjalan dengan lancar. Bank yang memiliki masalah seperti mengalami masalah likuiditas atau tidak mampu menjalankan fungsi sebagaimana mestinya dapat menjadi pertanda menurunnya kinerja bank, dan dapat menjadi sinyal yang buruk bagi nasabah. Hilangnya kepercayaan nasabah dapat menyebabkan bank akan memiliki citra yang buruk di masyarakat. Berbagai proksi untuk mengukur kesehatan bank telah diciptakan yang memiliki tujuan untuk membantu nasabah dan pihak-pihak yang berkepentingan untuk menilai kesehatan bank, dan dapat menjadi bahan pertimbangan untuk melakukan transaksi maupun menghimpun dana pada bank tersebut. Sebagai lembaga keuangan yang terpercaya, hendaknya bank mampu menjaga kinerjanya tetap baik dan memberikan kepuasan kepada nasabah, karena bagaimanapun nasabah menjadi faktor penting penentu keberlanjutan usaha perbankan.

Kesehatan bank berpengaruh pada kelangsungan operasional bank pada jangka Panjang. Bank yang sehat menarik keperyaan masyarakat untuk menanamkan modal bagi yang berkelebihan dan meminjam dana bagi yang membutuhkan. Sehat atau tidaknya bank dapat dilihat dari profitabilitasnya. Profitabilitas dapat diukur menggunakan ROA (Return On Asset) bank. ROA memfokuskan kemampuan bank untuk memperoleh return dari kegiatan operasi yang dijalankan bank dengan memanfaatkan aktiva yang dimiliki. ROA merupakan salah satu faktor yang dapat digunakan untuk menilai baik buruknya kinerja bank. Mengukur tingkat profitabilitas bank merupakan hal yang sangat penting, hal ini bertujuan untuk menjamin apakah keuntungan yang ditargetkan oleh bank dalam beberapa periode telah tercapai atau belum tercapai (Prasanjaya \& Ramantha, 2013). 
Berikut informasi ditampilkan dalam gambar 1 terkait rata-rata ROA Bank Umum Periode 2013-2015.

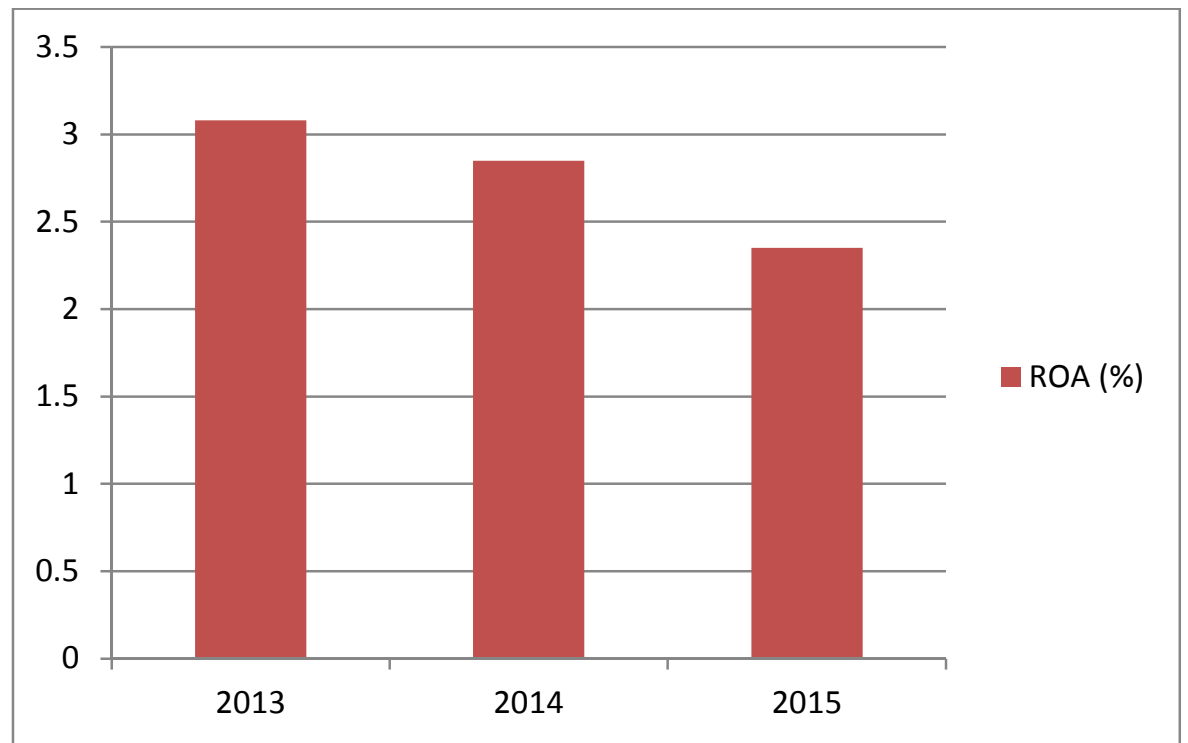

Gambar 1.Rata-Rata Return on Assets Bank Umum Periode 2013-2015 Sumber: Statistik Perbankan Indonesia, 2018

Gambar 1. menunjukkan bahwa ROA bank umum pada periode 2013-2015 sudah memenuhi nilai minimum yang ditetapkan oleh Bank Indonesia, yaitu sebesar 1,5 persen. Pada tahun 2013, nilai Return On Asset bank umum sebesar 3,08 persen, pada tahun 2014 turun menjadi 2,85 persen, dan pada tahun 2015 turun menjadi 2,35 persen.

Menurut Irawan Lubis, Deputi Komisioner Pengawas Perbankan OJK mengatakan bahwa ROA memang menurun karena bank menaikkan cadangan kerugian penurunan nilai (CKPN). Perlambatan pertumbuhan kredit yang disebabkan oleh perlambatan ekonomi domestik juga menjadi penyebab salah satu akan turunnya laba bank.

Dalam penentuan tingkat kesehatan suatu bank, Bank Indonesia lebih mementingkan penilaian Return On Asset daripada Return On Equity karena Bank Indonesia lebih mengutamakan nilai profitabilitas suatu bank yang diukur dengan asset yang dananya sebagian besar berasal dari dana simpanan masyarakat sehingga ROA lebih mewakili dalam mengukur tingkat profitabilitas perbankan (Julaeha, 2015).

ROA adalah rasio profitabilitas yang menunjukkan perbandingan antara laba (sebelum pajak) dengan total asset bank, rasio ini menunjukkan tingkat efisiensi pengelolaan asset yang dilakukan oleh bank yang bersangkutan (Riyadi, 2006). ROA semakin tinggi menunjukkan kinerja bank yang semakin baik pula, karena tingkat pengembalian atau return yang dihasilkan semakin besar.

Banyak variabel yang dapat mempengaruhi ROA, penelitian Dewi et al. (2015) menyatakan bahwa variabel-variabel yang mempengaruhi ROA adalah LDR, LAR, DER, dan CR. Lestari \& Widyawati (2014) berpendapat bahwa 
variabel-variabel yang mempengaruhi ROA yaitu CAR, NPL, LDR, dan BOPO. Penelitian Sukarno \& Syaichu (2006) menyatakan bahwa variabel-variabel yang berpengaruh terhadap ROA adalah CAR, LDR, NPL, DER, dan BOPO.

Dalam penelitian ini terdapat empat variabel bebas yang digunakan yaitu Capital Adequacy Ratio, Non Performing Loan, Debt to Equity Ratio, dan Loan to Asset Ratio. CAR (Capital Adequacy Ratio) merupakan rasio keuangan yang menunjukkan seberapa jauh seluruh aktiva bank yang mengandung risiko dibiayai dari modal bank baik yang berasal dari modal sendiri, dana dari masyarakat dan pinjaman. CAR berperan penting dalam mengurangi komponen risiko dalam industri perbankan, bank juga harus memiliki modal yang cukup untuk menyediakan dana baik untuk kebutuhan internal maupun untuk melakukan ekspansi (Almazari, 2013). Sama halnya dengan organisasi lain, bank mempunyai modal yang dapat digunakan untuk menjalankan aktivitas operasionalnya. Modal bank terdiri dari dua jenis yaitu modal inti serta modal pelengkap (Riyadi, 2006). Bank Indonesia menetapkan besar minimum dari rasio CAR yakni sebesar $8 \%$. Kecilnya CAR dapat menyebabkan turunnya kepercayaan masyarakat terhadap bank yang nantinya dapat menurunkan profitabilitas bank. Semakin tinggi CAR suatu bank, maka semakin tinggi pula ROA dari bank tersebut. Hal tersebut terjadi dikarenakan adanya modal yang besar, sehingga manajemen bank dapat dengan leluasa menempatkan dananya untuk berinvestasi pada asset yang menguntungkan.

Penelitian Sukarno \& Syaichu (2006) menunjukkan bahwa CAR berpengaruh positif dan signifikan terhadap ROA. Hasil penelitian Sukarno \& Syaichu (2006) bertentangan dengan penelitian yang dilakukan oleh Almazari (2013) dan Lestari \& Widyawati (2014) yang menunjukkan adanya pengaruh negatif antara CAR terhadap ROA.

Variabel kedua dalam penelitian ini yaitu Non Performing Loan (NPL). NPL menunjukkan perbandingan antara kredit yang bermasalah dengan total kredit yang diberikan. Semakin besar tingkat NPL menunjukkan bahwa bank tersebut tidak profesional dalam pengelolaan kreditnya, sekaligus memberikan indikasi bahwa tingkat risiko atas pemberian kredit pada bank tersebut cukup tinggi dan searah dengan tingginya NPL yang dihadapi bank (Riyadi, 2006). Semakin tinggi NPL suatu bank, maka ROA bank tersebut akan semakin kecil karena pendapatan laba perusahaan kecil.

Penelitian Eng (2013) menunjukkan bahwa NPL berpengaruh negatif dan signifikan terhadap ROA. Hasil penelitian Eng (2013) bertentangan dengan penelitian yang dilakukan oleh Sukarno \& Syaichu (2006) dan Lestari \& Widyawati (2014) yang menunjukkan adanya pengaruh positif antara NPL terhadap ROA.

Variabel ketiga adalah Debt to Equity Ratio (DER). Widati (2012) menyatakan DER digunakan untuk mengukur kemampuan bank dalam menyelesaikan sebagian atau seluruh utang, baik jangka pendek maupun jangka panjang dengan dana yang berasal dari modal bank sendiri. DER menggambarkan sejauh mana modal bank dapat menutupi utang-utang kepada pihak luar atau memperlihatkan sejauh mana bank tersebut dibiayai oleh utang. Sukarno \& Syaichu (2006) berpendapat bahwa, tingginya DER menunjukkan bahwa perusahaan akan memiliki masalah riil dalam jangka panjang, salah satunya adalah kemungkinan untuk terjadinya kebangkrutan. Semakin tinggi DER suatu bank, menunjukkan 
bahwa solvabilitas bank semakin rendah karena kemampuan membayar hutangnya rendah, hal ini mencerminkan risiko bank relatif tinggi.

Penelitian Dewi et al. (2015) menunjukkan bahwa DER berpengaruh negatif dan signifikan terhadap ROA. Hasil penelitian Dewi et al. (2015) bertentangan dengan penelitian yang dilakukan oleh Widati (2012), Barus \& Leliani (2013) yang menunjukkan adanya pengaruh positif antara DER terhadap ROA.

Variabel terakhir dalam penelitian ini yaitu Loan to Asset Ratio (LAR). LAR adalah perbandingan antara besarnya kredit yang diberikan bank dengan besarnya total asset yang dimiliki oleh bank. Semakin besar kredit yang diberikan bank, maka akan semakin besar pula pendapatan bunga yang akan diperoleh bank, sehingga pengembalian atas asset tersebut akan semakin tinggi.

Penelitian Dewi et al. (2015) menunjukkan bahwa LAR berpengaruh positif dan signifikan terhadap ROA. Hasil penelitian Dewi et al. (2015) bertentangan dengan penelitian yang dilakukan oleh Julaeha (2015) yang menunjukkan adanya pengaruh positif dan tidak signifikan antara LAR terhadap ROA.

CAR adalah ukuran dari jumlah modal bank yang dinyatakan dalam persentase dari Aktiva Tertimbang Menurut Risiko (Mekonnen, 2015). Menurut Kasmir (2012), CAR adalah rasio kinerja bank untuk mengukur kecukupan modal yang dimiliki bank untuk menunjang aktiva yang mengandung atau menghasilkan risiko, misalkan kredit yang diberikan bank. Jika nilai CAR tinggi berarti bank tersebut mampu membiayai operasi bank, keadaan yang menguntungkan bank tersebut akan memberikan kontribusi yang cukup besar bagi profitabilitas.

Modal yang memadai akan memberikan perlindungan utama terhadap kepailitan dan likuidasi yang timbul dari risiko dalam bisnis (Olalekan \& Adeyinka, 2013). Semakin tinggi CAR suatu bank, maka semakin tinggi pula ROA dari bank tersebut karena jumlah modal yang dimiliki bank akan lebih besar dari ATMR sehingga dapat meningkatkan pengembalian atas aset yang digunakan (ROA). Menurut Sukarno \& Syaichu (2006) CAR berpengaruh positif dan signifikan terhadap ROA karena semakin efisien modal bank yang digunakan untuk aktivitas operasional mengakibatkan bank mampu untuk meningkatkan labanya. Penelitian yang sama juga dilakukan oleh Havidz \& Setiawan (2015) dan Widati (2012) yang menyatakan bahwa CAR berpengaruh positif dan signifikan terhadap ROA. Berdasarkan kajian teori dan kajian empiris sebelumnya, maka dapat dirumuskan hipotesis sebagai berikut:

$\mathrm{H}_{1}$ : CAR berpengaruh positif dan signifikan terhadap ROA

Risiko kredit menunjukkan risiko yang terjadi jika peminjam gagal membayar semua jenis utang yang dimiliki pada saat waktu jatuh tempo (Alshatti, 2015). NPL merupakan persentase jumlah kredit bermasalah (dengan kriteria kurang lancar, diragukan dan macet) terhadap total kredit yang disalurkan bank (Lestari \& Widyawati, 2014). Menurut Buchory (2015) bahwa jika kredit gagal, maka kemampuan bank untuk memberikan pinjaman baru akan dibatasi. Peningkatan risiko kredit biasanya menunjukkan bahwa profitabilitas bank menurut Mawutor \& Fred (2015), NPL yang tinggi mengindikasikan bahwa pengelolaan kredit pada bank tidak optimal yang mengakibatkan risiko kredit yang dialami oleh bank tersebut akan menjadi tinggi. Semakin tinggi rasio dari NPL, maka akan menyebabkan semakin buruk pula kualitas kredit bank suatu bank yang artinya 
jumlah kredit bermasalah semakin besar, sehingga kemungkinan suatu bank dalam kondisi bermasalah akan semakin besar dan dapat mengakibatkan turunnya ROA suatu bank.

Menurut Eng (2013) NPL berpengaruh negatif dan signifikan terhadap ROA, karena NPL dapat membebani laba perbankan dan jika tidak dikelola dengan hatihati dapat mengurangi ROA bank. Penelitian yang sama juga dilakukan oleh Sunarto (2013) dan Sheefeni (2015) yang menyatakan bahwa NPL berpengaruh negatif dan signifikan terhadap ROA. Berdasarkan kajian teori dan kajian empiris sebelumnya, maka dapat dirumuskan hipotesis sebagai berikut:

$\mathrm{H}_{2}$ : NPL berpengaruh negatif dan signifikan terhadap ROA

DER merupakan rasio antara ekuitas dan hutang, dimana hutang mencakup kewajiban jangka panjang, jangka pendek, dan kewajiban lancar (Walsh, 2004). Menurut Sukarno \& Syaichu (2006) tingginya rasio ini menunjukkan bahwa perusahaan akan memiliki masalah riil dalam jangka panjang, salah satunya adalah kemungkinan untuk terjadinya kebangkrutan. Semakin besar hutang menyebabkan semakin besar pula risiko yang ditanggung, maka semakin besar pula kemungkinan atas penurunan ROA bank akan terjadi.

Menurut Dewi et al. (2015) DER berpengaruh negatif dan signifikan terhadap ROA, karena penggunaan hutang yang besar dari pihak ketiga untuk operasional bank dapat menambah beban bank yang nantinya dapat menurunkan ROA bank. Penelitian yang sama juga dilakukan oleh Ulzanah \& Murtaqi (2015), Enekwe et al. (2014), Kazumi et al. (2015) yang menyatakan bahwa DER berpengaruh negatif dan signifikan terhadap ROA. Enekwe et al. (2014) menyatakan bahwa penggunaan utang yang tinggi dibandingkan dengan ekuitas, berarti bahwa perusahaan secara agresif melakukan pembiayaan dengan utang. Hal ini dapat menambah beban bunga yang harus dibayar saat jatuh tempo, beban bunga yang terlalu besar menyebabkan ROA perusahaan akan menurun. Berdasarkan kajian teori dan kajian empiris sebelumnya, maka dapat dirumuskan hipotesis sebagai berikut:

$\mathrm{H}_{3}$ : DER berpengaruh negatif dan signifikan terhadap ROA

Menurut Kasmir (2012), LAR merupakan rasio untuk mengukur jumlah kredit yang disalurkan dengan jumlah asset yang dimiliki bank. Kemungkinan pendapatan bunga yang diperoleh bank atas penyaluran kredit tersebut akan semakin tinggi, jika jumlah kredit yang disalurkan bank semakin tinggi.

Menurut Dewi et al. (2015) LAR berpengaruh positif dan signifikan terhadap ROA, semakin besar kredit yang diberikan bank, maka akan semakin besar pula pendapatan bunga yang akan diperoleh bank, sehingga pengembalian atas asset tersebut akan semakin tinggi. Penelitian yang sama juga dilakukan oleh Julita (2011) dan Anggraini (2014) yang menyatakan bahwa LAR berpengaruh positif dan signifikan terhadap ROA. Berdasarkan kajian teori dan kajian empiris sebelumnya, maka dapat dirumuskan hipotesis sebagai berikut:

$\mathrm{H}_{4}$ : LAR berpengaruh positif dan signifikan terhadap ROA

Profitabilitas menunjukkan kemampuan perusahaan memperoleh laba atau ukuran efektivitas pengelolaan manajemen perusahaan. Menurut Riyadi (2006) rasio profitabilitas adalah perbandingan laba setelah pajak dengan modal atau laba sebelum pajak dengan total aset yang dimiliki bank pada periode tertentu. Jadi, 
profitabilitas yaitu kemampuan bank atau perusahaan dalam menghasilkan laba dengan memanfaatkan asset atau modal yang dimilikinya.

Jika sistem keuangan cukup efisien, maka akan menunjukkan peningkatan profitabilitas, peningkatan volume dana yang mengalir dari penabung ke peminjam, dan kualitas layanan yang lebih baik bagi konsumen. Peningkatan profitabilitas akan dapat membantu operasional bank lebih baik dalam menjalankan usahanya yakni dapat mencegah bank untuk menggunakan utang lebih sedikit dalam struktur modalnya. Selain itu, profitabilitas yang tinggi dapat membantu bank dalam mengantisipasi risiko likuiditas. Penilaian terhadap faktor pendapatan meliputi penilaian terhadap beberapa komponen yaitu kemampuan bank dalam menghasilkan laba, kapasitas penghasilan untuk mendukung ekspansi dan mengcover risiko, serta tingkat efisiensi bank.

Kemampuan bank atau perusahaan dalam memperoleh laba dapat diukur dari seluruh dana yang diinvestasikan ke dalam bank baik berasal dari modal sendiri maupun dari sumber dana lainnya. Dengan itu, profitabilitas bank dapat diukur dari berapa besar laba yang diperoleh bank pada saat periode tertentu dan berapa modal yang digunakan oleh bank dalam menghasilkan laba tersebut. Umumnya profitabilitas bank memiliki hubungan kausalitas dengan nilai perusahaan. Hubungan kausalitas ini menunjukkan bahwa apabila kinerja manajemen perusahaan yang diukur menggunakan dimensi-dimensi profitabilitas dalam kondisi baik, maka akan memberikan dampak positif terhadap keputusan investor di pasar modal untuk menanamkan modalnya dalam bentuk penyertaan modal, demikian halnya juga akan berdampak pada keputusan kreditor dalam kaitannya dengan pendanaan perusahaan melalui utang.

Dalam penelitian ini terdapat empat variabel bebas yang digunakan yaitu Capital Adequacy Ratio, Non Performing Loan, Debt to Equity Ratio, dan Loan to Asset Ratio. CAR (Capital Adequacy Ratio) merupakan rasio keuangan yang menunjukkan seberapa jauh seluruh aktiva bank yang mengandung risiko dibiayai dari modal bank baik yang berasal dari modal sendiri, dana dari masyarakat dan pinjaman. CAR berperan penting dalam mengurangi komponen risiko dalam industri perbankan, bank juga harus memiliki modal yang cukup untuk menyediakan dana baik untuk kebutuhan internal maupun untuk melakukan ekspansi (Almazari, 2013). Sama halnya dengan organisasi lain, bank mempunyai modal yang dapat digunakan untuk menjalankan aktivitas operasionalnya. Modal bank terdiri dari dua jenis yaitu modal inti serta modal pelengkap (Riyadi, 2006). Bank Indonesia menetapkan besar minimum dari rasio CAR yakni sebesar $8 \%$. Kecilnya CAR dapat menyebabkan turunnya kepercayaan masyarakat terhadap bank yang nantinya dapat menurunkan profitabilitas bank. Semakin tinggi CAR suatu bank, maka semakin tinggi pula ROA dari bank tersebut. Hal tersebut terjadi dikarenakan adanya modal yang besar, sehingga manajemen bank dapat dengan leluasa menempatkan dananya untuk berinvestasi pada asset yang menguntungkan.

\section{METODE PENELITIAN}

Ruang lingkup wilayah penelitian ini yaitu bank-bank umum di Bursa Efek Indonesia periode 2013-2015, dengan mengakses website www.idx.co.id. Obyek 
dari penelitian ini yaitu Return On Assets (ROA) pada bank-bank umum di Bursa Efek Indonesia periode 2013-2015.

Return on Asset (ROA) merupakan perbandingan antara laba sebelum pajak dengan total asset bank pada bank umum di BEI periode 2013-2015, yang diukur menggunakan skala rasio dengan satuan persentase. Menurut Riyadi (2006), ROA dapat dihitung menggunakan rumus sebagai berikut.

$$
R O A=\frac{\text { Laba Sebelum Pajak }}{\text { Total Aset }} \times 100 \%
$$

Capital Adequacy Ratio (CAR) merupakan perbandingan antara jumlah modal dengan Aktiva Tertimbang Menurut Risiko (ATMR) pada bank umum di BEI periode 2013-2015, yang diukur menggunakan skala rasio dengan satuan persentase. CAR dapat dihitung dengan rumus sebagai berikut (Riyadi, 2006).

$$
C A R=\frac{\text { Modal }}{\text { ATMR }} \times 100 \%
$$

Non Performing Loan (NPL) merupakan perbandingan antara jumlah kredit yang bermasalah dengan total kredit yang diberikan bank umum di BEI periode 2013-2015, yang diukur menggunakan skala rasio dengan satuan persentase. NPL dapat dihitung dengan rumus sebagai berikut (Julaeha, 2015).

$$
N P L=\frac{\text { Kredit Bermasalah }}{\text { Total Kredit yang Diberikan }} \times 100 \%
$$

Debt to Equity Ratio (DER) merupakan perbandingan antara hutang dengan modal bank umum di BEI periode 2013-2015, yang diukur menggunakan skala rasio dengan satuan persentase. DER dapat dihitung dengan rumus sebagai berikut (Enekwe et al., 2014).

$$
\text { DER }=\frac{\text { Total Hutang }}{\text { Total Ekuitas }} \times 100 \%
$$

Loan to Asset Ratio (LAR) merupakan perbandingan antara total loans dengan total assets bank umum di BEI periode 2013-2015, yang diukur menggunakan skala rasio dengan satuan persentase. LAR dapat dihitung dengan rumus sebagai berikut (Kasmir, 2012).

$$
L A R=\frac{\text { Total Loans }}{\text { Total Assets }} \times 100 \%
$$

Populasi dalam penelitian ini adalah seluruh perusahaan perbankan di Bursa Efek Indonesia yang konsisten listing periode 2013-2015 yakni sebanyak 31 perusahaan perbankan. Penelitian ini merupakan penelitian berdasarkan sensus yaitu penelitian yang menggunakan seluruh anggota dalam populasi sebagai sampel. Oleh karena penelitian ini bekerja dengan sensus, maka jumlah sampel yang digunakan dalam penelitian ini sebanyak 31 perusahaan perbankan.

Metode analisis data yang digunakan dalam penelitian ini adalah analisis regresi linier berganda. Regresi linear berganda adalah suatu metode statistik yang digunakan untuk meneliti hubungan atau pengaruh antara sebuah variabel terikat dengan beberapa variabel bebas yang diproses menggunakan program Statistical Package for Social Science (SPSS). Analisis regresi linier berganda dalam penelitian ini digunakan untuk mengetahui pengaruh Capital Adequacy Ratio, Non Performing Loan, Debt to Equity Ratio, dan Loan to Asset Ratio terhadap Return 
On Asset pada bank umum di BEI periode 2013-2015. Persamaan regresi linier berganda adalah sebagai berikut:

$\mathrm{Y}=\mathrm{a}+\mathrm{b}_{1} \mathrm{X}_{1}+\mathrm{b}_{2} \mathrm{X}_{2}+\mathrm{b}_{3} \mathrm{X}_{3}+\mathrm{b}_{4} \mathrm{X}_{4}+\varepsilon$

Keterangan:

$\mathrm{Y} \quad$ : Return On Asset

$\mathrm{X}_{1} \quad$ : Capital Adequacy Ratio

$\mathrm{X}_{2} \quad$ : Non Performing Loan

$\mathrm{X}_{3} \quad$ : Debt to Equity Ratio

$\mathrm{X}_{4} \quad$ : Loan to Asset Ratio

bi : Koefisien regresi

a : Konstanta

$\varepsilon \quad$ : Kesalahan residual (error)

\section{HASIL DAN PEMBAHASAN}

ROA merupakan laba yang mampu diperoleh bank dengan memanfaatkan asset yang dimiliki dalam menjalankan kegiatan usahanya. ROA dalam penelitian ini dihitung dengan membandingkan antara laba sebelum pajak dengan total asset bank pada bank umum di BEI periode 2013-2015.

Tabel 1.

Statistik Deskriptif Return on Assets (ROA)

\begin{tabular}{cccccc}
\hline Variabel & N & Minimum & Maximum & Mean & Std. Deviation \\
\hline ROA & 93 & $-7,58$ & 5,14 & 1,5571 & 2,06720 \\
\hline Sumber: Data diolah, 2019 & & & &
\end{tabular}

Tabel 1. merupakan statistik deskriptif ROA pada bank umum di BEI periode 2013-2015. Rata-rata nilai ROA sebesar 1,5571 dengan standar deviasi 2,06720. Nilai standar deviasi yang lebih besar dibandingkan dengan nilai rata-rata mengindikasikan tinginya kesenjangan atau variasi dari data ROA yang menjadi sampel penelitian. Nilai variabel ROA tertinggi adalah PT. Bank Himpunan Saudara 1906, Tbk yaitu sebesar 5,14 persen pada tahun 2013 sementara yang terendah sebesar -7,58 persen yaitu PT. Bank Mutiara, Tbk pada tahun 2015.

CAR adalah rasio kecukupan modal yang menunjukkan kompetensi bank dalam mempertahankan modalnya atas aktiva bank yang mengandung risiko. CAR dalam penelitian ini diukur dengan membandingkan antara jumlah modal dengan Aktiva Tertimbang Menurut Risiko (ATMR) bank pada bank umum di BEI periode 2013-2015.

Tabel 2.

Statistik Deskriptif Capital Adequacy Ratio (CAR)

\begin{tabular}{cccccc}
\hline Variabel & $\mathbf{N}$ & Minimum & Maximum & Mean & Std. Deviation \\
\hline CAR & 93 & 8,02 & 27,91 & 17,1431 & 3,47046 \\
\hline
\end{tabular}

Sumber: Data diolah, 2019

Tabel 2. merupakan statistik deskriptif CAR pada bank umum di BEI periode 2013-2015. Rata-rata nilai CAR sebesar 17,1431 dengan standar deviasi 3,47046. Nilai standar deviasi yang lebih kecil dibandingkan dengan nilai rata-rata 
menandakan bahwa rendahnya kesenjangan atau variasi dari data CAR yang menjadi sampel penelitian. Nilai variabel CAR tertinggi adalah PT. Bank Himpunan Saudara 1906, Tbk yaitu sebesar 27,91 persen pada tahun 2013 sementara yang terendah sebesar 8,02 persen yaitu PT. Bank Pundi Indonesia, Tbk pada tahun 2015.

NPL akan muncul jika pinjaman yang diberikan bank tidak mampu lagi menghasilkan bunga atau debitur tidak mampu lagi membayar kewajibannya. NPL dalam penelitian ini dihitung dengan membandingkan antara jumlah kredit yang bermasalah dengan total kredit yang diberikan bank pada bank umum di BEI periode 2013-2015.

Tabel 3.

Statistik Deskriptif Non Performing Loan (NPL)

\begin{tabular}{cccccc}
\hline Variabel & N & Minimum & Maximum & Mean & Std. Deviation \\
\hline NPL & 93 &, 21 & 12,28 & 2,5180 & 2,04362 \\
\hline
\end{tabular}

Sumber: Data diolah, 2019

Tabel 3. merupakan statistik deskriptif NPL pada bank umum di BEI periode 2013-2015. Rata-rata nilai NPL sebesar 2,5180 dengan standar deviasi 2,04362. Nilai standar deviasi yang lebih kecil dibandingkan dengan nilai rata-rata mengindikasikan rendahnya kesenjangan atau variasi dari data NPL yang menjadi sampel penelitian. Nilai variabel NPL tertinggi adalah PT. Bank Mutiara, Tbk yaitu sebesar 12,28 persen pada tahun 2013 sementara yang terendah sebesar 0,21 persen yaitu PT. Bank Bumi Arta, Tbk pada tahun 2013.

DER merupakan rasio yang digunakan untuk mengukur seberapa jauh kemampuan modal bank dalam membiayai utangnya. DER dalam penelitian ini dihitung dengan membandingkan antara hutang dengan modal bank pada bank umum di BEI periode 2013-2015.

Tabel 4.

Statistik Deskriptif Debt to Equity Ratio (DER)

\begin{tabular}{cccccc}
\hline Variabel & N & Minimum & Maximum & Mean & Std. Deviation \\
\hline DER & 93 & 277,55 & 1820,75 & 768,9910 & 250,45089 \\
\hline Sumber:
\end{tabular}

Sumber: Data diolah, 2019

Tabel 4. merupakan statistik deskriptif DER pada bank umum di BEI periode 2013-2015. Rata-rata nilai DER sebesar 768,9910 dengan standar deviasi 250,45089. Nilai standar deviasi yang lebih kecil dibandingkan dengan nilai ratarata mengindikasikan rendahnya kesenjangan atau variasi dari data DER yang menjadi sampel penelitian. Nilai variabel DER tertinggi adalah PT. Bank Pundi Indonesia, Tbk yaitu sebesar 1820,75 persen pada tahun 2015 sementara yang terendah sebesar 277,55 persen yaitu PT. Bank Himpunan Saudara 1906, Tbk pada tahun 2013.

LAR yaitu rasio yang digunakan untuk mengukur kemampuan bank dalam menyalurkan kredit dengan menggunakan total aset yang dimilikinya. LAR dalam penelitian ini dihitung dengan membandingkan antara total loans dengan total assets bank pada bank umum di BEI periode 2013-2015. 
Tabel 5.

Statistik Deskriptif Loan to Asset Ratio (LAR)

\begin{tabular}{|c|c|c|c|c|c|}
\hline Variabel & $\mathbf{N}$ & Minimum & Maximum & Mean & Std. Deviation \\
\hline LAR & 93 & 45,44 & 80,70 & 66,9446 & 6,73325 \\
\hline
\end{tabular}

Sumber: Data diolah, 2019

Tabel 5. merupakan statistik deskriptif LAR pada bank umum di BEI periode 2013-2015. Rata-rata nilai LAR sebesar 66,9446 dengan standar deviasi 6,73325. Nilai standar deviasi yang lebih kecil dibandingkan dengan nilai rata-rata mengindikasikan rendahnya kesenjangan atau variasi dari data LAR yang menjadi sampel penelitian. Nilai variabel LAR tertinggi adalah PT. Bank QNB Indonesia, Tbk yaitu sebesar 80,70 persen pada tahun 2015 sementara yang terendah sebesar 45,44 persen yaitu PT. Bank Mega, Tbk pada tahun 2013.

Uji asumsi klasik dalam penelitian ini digunakan untuk menguji kelayakan model yang dibuat sebelum digunakan untuk memprediksi. Uji asumsi klasik terdiri dari uji normalitas, uji multikolinearitas, uji heteroskedastisitas dan uji autokorelasi.

Tabel 6.

Hasil Uji Normalitas

\begin{tabular}{lc}
\hline & Unstandardized Residual \\
\hline $\mathrm{N}$ & 93 \\
Kolmogorov-Smirnov &, 081 \\
Asymp. Sig. (2-tailed) &, 161 \\
\hline Sumber: Data diolah, 2017
\end{tabular}

Uji normalitas bertujuan untuk mengetahui apakah dalam residual dari model regresi yang dibuat berdistribusi normal atau tidak. Model regresi yang baik yaitu model yang memiliki distribusi residual yang normal atau mendekati normal. Uji yang dapat digunakan dalam uji normalitas adalah uji Kolmogorov-Smirnov (K-S). Data dikatakan berdistribusi normal jika taraf signifikansi lebih besar dari 0,05. Berdasarkan hasil analisis pada Tabel 6 diperoleh nilai signifikansi sebesar 0,161 lebih besar dari 0,05 maka data dapat dikatakan terdistribusi secara normal.

Uji multikolinearitas bertujuan untuk menguji apakah dalam suatu model regresi ditemukan adanya korelasi antar variabel bebas. Model regresi dikatakan baik jika tidak terjadi korelasi diantara variabel bebas. Mendeteksi ada atau tidaknya korelasi antar variabel dapat dilihat dari nilai tolerance di atas 0,10 dan nilai Variance Inflation Factor (VIF) di bawah 10 yang berarti tidak terdapat gejala multikolinearitas.

Tabel 7.

Hasil Uji Multikolinearitas

\begin{tabular}{ccc}
\hline Variabel & Nilai tolerance & Nilai VF \\
\hline CAR & 0,398 & 2,513 \\
NPL & 0,811 & 1,233 \\
DER & 0,388 & 2,577 \\
LAR & 0,952 & 1,050 \\
\hline
\end{tabular}

Sumber: Data diolah, 2017 
Hasil uji multikolinearitas pada Tabel 7. menunjukkan nilai tolerance untuk setiap variabel bebas lebih besar dari 0,10 dan nilai VIF-nya lebih kecil dari 10, sehingga model regresi dalam penelitian ini dapat dikatakan bebas dari multikolinearitas.

Model regresi dikatakan baik jika model tidak mengandung gejala heteroskedastisitas atau mempunyai varian yang homogen. Uji yang digunakan adalah Uji Glejser. Model regresi ini bebas dari masalah heteroskedastisitas, jika tingkat signifikansi berada di atas 0,05 .

Tabel 8.

Hasil Uji Heteroskedastisitas

\begin{tabular}{ccc}
\hline Variabel & Sig. & Keterangan \\
\hline CAR & 0,398 & Bebas heteroskedastisitas \\
NPL & 0,811 & Bebas heteroskedastisitas \\
DER & 0,388 & Bebas heteroskedastisitas \\
LAR & 0,952 & Bebas heteroskedastisitas \\
\hline
\end{tabular}

Sumber: Data diolah, 2017

Hasil uji heteroskedastisitas pada Tabel 7. menunjukkan bahwa keseluruhan variabel memiliki nilai signifikansi melebihi 0,05 sehingga data penelitian dapat disimpulkan terbebas dari heteroskedastisitas.

Uji autokorelasi dalam penelitian ini digunakan untuk menguji ada tidaknya korelasi antara variabel pada periode tertentu dengan variabel periode sebelumnya. Model regresi dikatakan baik jika tidak terjadi autokorelasi. Mendeteksi adanya data autokorelasi dapat dilihat dari nilai Durbin-Watson (DW), apabila nilai Durbin Watson berada diantara nilai $\mathrm{d}_{\mathrm{U}}$ dan $4-\mathrm{d}_{\mathrm{u}}$ maka tidak ada gejala autokorelasi.

Tabel 9.

Hasil Uji Autokorelasi

\begin{tabular}{llllll}
\hline Model & R & R Square & $\begin{array}{l}\text { Adjusted } \\
\text { R Square }\end{array}$ & $\begin{array}{l}\text { Std. Error of the } \\
\text { Estimate }\end{array}$ & Durbin-Watson \\
\hline 1 &, $745(\mathrm{a})$ &, 556 &, 535 & 1,40907 & 1,773 \\
\hline Sumber: Data diolah, 2017 & & &
\end{tabular}

Hasil uji autokorelasi pada Tabel 9. menunjukkan nilai D-W sebesar 1,773 dengan nilai $\mathrm{d}_{\mathrm{L}}=1,5741$ dan $\mathrm{d}_{\mathrm{U}}=1,7531$ sehingga $4-\mathrm{d}_{\mathrm{L}}=4-1,5741=2,4259$ dan $4-\mathrm{d}_{\mathrm{U}}=4-1,7531=2,2469$. Nilai $\mathrm{d}_{\mathrm{L}}$ dan $\mathrm{d}_{\mathrm{U}}$ diperoleh dari tabel DW dengan kriteria sampel sebanyak 93 dan variabel bebas sebanyak 4. Model regresi tidak terjadi gejala autokorelasi karena nilai dwstatistic 2,059 berada diantara $\mathrm{d}_{\mathrm{U}}$ dan $4-\mathrm{d}_{\mathrm{U}}$ $(1,7531<1,773<2,2469)$.

Analisis regresi linier berganda digunakan untuk mengetahui pengaruh CAR, NPL, DER dan LAR perusahaan terhadap ROA pada Bank Umum di Bursa Efek Indonesia. Melalui analisis regresi ini dapat diketahui bagaimana pengaruh variabel bebas pada variabel terikat, apakah berpengaruh positif signifikan, ataupun berpengaruh negatif yang dilihat dari nilai konstanta, beta, nilai signifikansi masing-masing variabel, nilai koefisien determinasi juga bisa dilihat pada table hasil analisis regresi linear berganda. Dari tabel tersebut juga dapat dianalisis variabel mana yang masih perlu d tingkatkat sebagai saran bagi bank untuk kinerja selanjutnya. Hasil dari analisis regresi linier berganda ditunjukkan pada Tabel 10 . 
Tabel 10.

Ringkasan Hasil Analisis Regresi Linier Berganda

\begin{tabular}{lll}
\hline Variabel & Koefisien Regresi & Sig. \\
\hline CAR & 0,319 & 0,006 \\
NPL & $-0,471$ & 0,000 \\
DER & $-0,089$ & 0,044 \\
LAR & 0,145 & 0,049 \\
R Square & $=0,556$ & $\mathrm{~F}=27,502$ \\
\hline Adj. R Square $=0,535$ & Sig. $=0,000$ \\
\hline
\end{tabular}

Sumber: Data diolah, 2017

Berdasarkan hasil analisis pada Tabel 10. maka persamaan regresi yang digunakan dalam penelitian ini dapat ditulis sebagai berikut:

$\mathrm{Y}=0,319 \mathrm{X}_{1}-0,471 \mathrm{X}_{2}-0,089 \mathrm{X}_{3}+0,145 \mathrm{X}_{4}$

Keterangan :

$\mathrm{Y}=\mathrm{ROA}$

$\mathrm{X}_{1}=\mathrm{CAR}$

$\mathrm{X}_{2}=\mathrm{NPL}$

$\mathrm{X}_{3}=\mathrm{DER}$

$\mathrm{X}_{4}=\mathrm{LAR}$

Variabel CAR memiliki koefisien regresi sebesar 0,319, berarti bahwa apabila CAR naik sebesar 1\% maka ROA akan naik sebesar 31,9\% dengan asumsi bahwa variabel independen lain konstan.

Variabel NPL memiliki koefisien regresi sebesar $-0,471$, berarti bahwa apabila NPL naik sebesar 1\% maka ROA akan turun sebesar 47,1\% dengan asumsi bahwa variabel independen lain konstan.

Variabel DER memiliki koefisien regresi sebesar -0,089, berarti bahwa apabila DER naik sebesar 1\% maka ROA akan turun sebesar 8,9 \% dengan asumsi bahwa variabel independen lain konstan.

Variabel LAR memiliki koefisien regresi sebesar 0,145, berarti bahwa apabila LAR naik sebesar 1\% maka ROA akan naik sebesar 14,5 \% dengan asumsi bahwa variabel independen lain konstan.

Koefisien determinasi $\left(\mathrm{R}^{2}\right)$ digunakan untuk mengukur seberapa jauh variasi variabel dependen dapat dijelaskan oleh variabel independennya. Tabel 4.10 memperlihatkan bahwa besarnya nilai $\mathrm{R}$ square adalah sebesar 0,556 ini berarti bahwa 55,6 persen variasi ROA dipengaruhi oleh CAR, NPL, DER dan LAR sedangkan sisanya 44,4 persen dipengaruhi oleh faktor-faktor lain yang tidak dimasukkan dalam model penelitian, seperti LDR, NPM, dan proksi-proksi lainnya yang dapat digunakan dalam mengukur tingkat kesehatan bank selain proksi-proksi yang telah digunakan dalam penelitian ini.

Uji simultan atau uji $\mathrm{F}$ berfungsi untuk mengetahui pengaruh variabel bebas terhadap variabel terikat secara simultan, apakah pengaruhnya positif maupun negative. Pengaruh variabel bebas terhadap variabel terikat dinilai dapat berpengaruh signifikan jika nilai probabilitas lebih kecil dari taraf signifikansi pada penelitian ini yaitu sebesar 5\% $(0,05)$. Uji F dapat dilihat pada tabel analisis regresi linear berganda. Hasil Uji Simultan atau Uji F dapat dilihat pada Tabel 11. 
Tabel 11.

Ringkasan Hasil Uji F

\begin{tabular}{cccccc}
\hline Model & Sum of Squares & Df & Mean Square & F & Sig \\
\hline Regression & 218,422 & 4 & 54,606 & 27,502 &, $000 \mathrm{~b}$ \\
Residual & 174,723 & 88 & 1,985 & & \\
Total & 393,145 & 92 & & & \\
\hline
\end{tabular}

Sumber: Data diolah, 2017

Berdasarkan Tabel 11. dapat diketahui bahwa nilai signifikansi sebesar 0,000 lebih kecil dari taraf signifikansi yaitu sebesar 0,05 . Hal tersebut mengindikasikan bahwa CAR, NPL, DER dan LAR secara simultan berpengaruh positif signifikan terhadap ROA pada bank umum di BEI periode 2013-2015.

Tabel 12.

Ringkasan Hasil Uji t

\begin{tabular}{cccc}
\hline Variabel & Koefisien Regresi & thitung & Sig. \\
\hline CAR & 0,190 & 2,830 & 0,006 \\
NPL & $-0,477$ & $-5,976$ & 0,000 \\
DER & $-0,001$ & $-0,776$ & 0,044 \\
LAR & 0,045 & 1,993 & 0,049 \\
\hline
\end{tabular}

Sumber: Data diolah, 2017

Tabel 12. menunjukkan bahwa nilai sig. sebesar 0,006 lebih kecil dari 0,05.Nilai t hitung sebesar 2,830 dengan tanda positif memiliki arti bahwa CAR mempunyai hubungan yang positif signifikan dengan ROA Bank Umum di BEI periode 2013-2015. Hasil ini menunjukkan bahwa $\mathrm{H}_{0}$ ditolak dan $\mathrm{H}_{1}$ yang menyatakan CAR berpengaruh positif signifikan terhadap ROA dalam penelitian ini diterima. Tabel 12. menunjukkan bahwa nilai sig. sebesar 0,000 lebih kecil dari 0,05. Nilai t hitung sebesar $-5,976$ dengan tanda negatif memiliki arti bahwa NPL mempunyai hubungan yang negatif signifikan dengan ROA Bank Umum di BEI periode 2013-2015. Hasil ini menunjukkan bahwa $\mathrm{H}_{0}$ ditolak dan $\mathrm{H}_{2}$ yang menyatakan NPL berpengaruh negatif signifikan terhadap ROA dalam penelitian ini diterima. Tabel 12. menunjukkan bahwa nilai sig. sebesar 0,044 lebih kecil dari 0,05.Nilai t hitung sebesar -0,776 dengan tanda negatif memiliki arti bahwa DER mempunyai hubungan yang negatif signifikan dengan ROA Bank Umum di BEI periode 2013-2015. Hasil ini menunjukkan bahwa $\mathrm{H}_{0}$ ditolak dan $\mathrm{H}_{3}$ yang menyatakan DER berpengaruh negatif signifikan terhadap ROA dalam penelitian ini diterima. Tabel 12. menunjukkan bahwa nilai sig. sebesar 0,049 lebih kecil dari 0,05. Nilai t hitung sebesar 1,993 dengan tanda positif memiliki arti bahwa LAR mempunyai hubungan yang positif signifikan dengan ROA Bank Umum di BEI periode 2013-2015. Hasil ini menunjukkan bahwa $\mathrm{H}_{0}$ ditolak dan $\mathrm{H}_{4}$ yang menyatakan LAR berpengaruh positif signifikan terhadap ROA dalam penelitian ini diterima.

Hasil dari penelitian ini menunjukkan bahwa CAR berpengaruh positif signifikan terhadap ROA pada Bank Umum di BEI periode 2013-2015. Hal ini terlihat dari nilai koefisien regresi sebesar 0,319 dan nilai sig. thitung sebesar 0,006 lebih kecil dari 0,05 yang dapat diartikan bahwa ada pengaruh positif signifikan antara CAR terhadap ROA. 
Hasil penelitian ini sejalan dengan penelitian yang dilakukan oleh Sukarno \& Syaichu (2006), Havidz \& Setiawan (2015) dan Widati (2012) yang menyatakan bahwa CAR berpengaruh positif dan signifikan terhadap ROA. Semakin efesien bank dalam menggunakan modal untuk kegiatan operasionalnya mengakibatkan bank mampu memperoleh laba yang lebih tinggi. Pihak manajemen bank harus memperhatikan besarnya CAR agar tetap ideal, karena modal yang terlalu besar dapat menyebabkan idle fund dan sebaliknya bila modal bank terlalu kecil menyebabkan bank akan kehilangan kepercayaan dari masyarakat. Ketika bank kehilangan kepercayaan dari masyarakat, maka dana pihak ketiga bank dimungkinkan akan mengalami penurunan secara drastis.

Modal dasar dari perusahaan perbankan adalah kepercayaan masyarakat terhadap bank, sehingga kepercayaan masyarakat harus dijaga demi kelangsungan hidup bank dan kelancaran dalam kegiatan operasionalnya. Tingkat CAR yang ideal sangat menguntungkan bagi bank karena bank akan dapat menginvestasikan dananya pada asset yang menguntungkan dan dapat meningkatkan kepercayaan masyarakat, sehingga masyarakat akan memiliki keingininan untuk menyimpan dananya di bank.

Sebaliknya perbedaan penelitian yang dilakukan oleh Almazari (2013) dan Lestari \& Widyawati (2014) menyatakan bahwa CAR berpengaruh negatif signifikan terhadap ROA. CAR yang tinggi dapat menyebabkan berkurangnya kemampuan bank untuk melakukan ekspansi usaha karena semakin besar cadangan modal yang diperlukan untuk menutupi risiko kerugian. Terhambatnya ekspansi usaha akibat tingginya CAR pada akhirnya dapat menyebabkan turunnya laba bank. Terdapatnya perbedaan hasil penelitian disebabkan oleh perbedaan lokasi penelitian dan perbedaan periode penelitian.

Hasil dari penelitian ini menunjukkan bahwa NPL berpengaruh negatif signifikan terhadap ROA pada Bank Umum di BEI periode 2013-2015. Hal ini terlihat dari nilai koefisien regresi sebesar $-0,471$ dan nilai sig. $t_{\text {hitung }}$ sebesar 0,000 lebih kecil dari 0,05 yang dapat diartikan bahwa ada pengaruh negatif signifikan antara NPL terhadap ROA.

Hasil penelitian ini sejalan dengan penelitian yang dilakukan oleh Eng (2013), Sunarto (2013) dan Sheefeni (2015) yang menyatakan bahwa NPL berpengaruh negatif dan signifikan terhadap ROA. Semakin tinggi NPL suatu bank, maka akan semakin buruk kualitas kredit bank yang akan mengakibatkan jumlah kredit bermasalah semakin besar. NPL yang semakin tinggi memungkinkan bank dalam kondisi bermasalah semakin besar. Kredit bermasalah yaitu kredit dengan kualitas kurang lancar, diragukan dan macet. Semakin tinggi NPL akan mengakibatkan menurunnya ROA bank karena semakin besar jumlah nasabah yang tidak membayar kewajibannya, sehingga pendapatan bank yang berasal dari bunga kredit akan menurun. Begitu pula sebaliknya, jika NPL turun maka ROA bank akan semakin meningkat.

Sebaliknya perbedaan penelitian yang dilakukan oleh Sukarno \& Syaichu (2006) dan Lestari \& Widyawati (2014) menyatakan bahwa NPL berpengaruh positif signifikan terhadap ROA. Bank sebagai lembaga yang bergerak dalam bidang jasa keuangan, maka bank memberikan berbagai fasilitas kepada nasabah. Salah satu fasilitas yang diberikan kepada nasabah adalah loanable funds dalam 
bentuk fasilitas kredit. Akan tetapi sebagian dana itu disisihkan dalam bentuk penanaman lain, yaitu surat-surat berharga, penempatan dana pada bank lain dan penyertaan modal bank pada lembaga keuangan yang bukan bentuk bank atau perusahaan lain (Syahyunan, 2002).

NPL merupakan rasio yang menunjukkan tingkat kredit yang merupakan salah satu bentuk dari loanable funds yang mengalami permasalahan dalam suatu bank. Permasalahan akan semakin rumit bila bank dalam rangka memperoleh profit, hanya berkonsentrasi pada pengelolaan earning assets yang berupa kredit dan kurang memperhatikan earning assets dalam bentuk lain seperti surat-surat berharga, penempatan dana pada bank lain, dan penyertaan modal bank pada lembaga keuangan yang bukan bentuk bank atau perusahaan lain (fee base income). Dalam rangka mengurangi dampak negatif dari adanya risiko kredit NPL yang tinggi, fee base income memiliki peranan yang sangat penting dalam menutup kerugian yang timbul akibat risiko kredit sehingga ROA bank tetap tinggi. Terdapatnya perbedaan hasil penelitian disebabkan oleh perbedaan lokasi penelitian dan perbedaan periode penelitian.

Hasil dari penelitian ini menunjukkan bahwa DER berpengaruh negatif signifikan terhadap ROA pada Bank Umum di BEI periode 2013-2015. Hal ini terlihat dari nilai koefisien regresi sebesar $-0,089$ dan nilai sig. $t_{\text {hitung }}$ sebesar 0,044 lebih kecil dari 0,05 yang dapat diartikan bahwa ada pengaruh negatif signifikan antara DER terhadap ROA.

Hasil penelitian ini sejalan dengan penelitian yang dilakukan oleh Dewi et al. (2015), Ulzanah \& Murtaqi (2015), Enekwe et al. (2014) dan Kazumi et al. (2015) yang menyatakan bahwa DER berpengaruh negatif dan signifikan terhadap ROA. Semakin besar komponen hutang yang digunakan bank dalam menjalankan kegiatan operasionalnya, maka akan memberikan dampak yang buruk terhadap profitabilitas bank. Semakin tinggi DER yang dimiliki bank, maka tingkat untuk memperoleh laba (ROA) akan semakin rendah. Apabila tingkat bunga pinjaman bank lebih tinggi dibandingkan pendapatan bunga bank, maka bank akan mengalami permasalahan dalam membayar hutang karena laba yang mampu diperoleh bank rendah.

Sebaliknya perbedaan penelitian yang dilakukan oleh Widati (2012) dan Barus \& Leliani (2013) menyatakan bahwa DER berpengaruh positif signifikan terhadap ROA. Semakin tinggi DER menunjukkan bahwa total hutang yang tinggi dimana banyaknya dana kreditor yang masuk sehingga dapat digunakan untuk menghasilkan atau meningkatkan laba (ROA). Bila hutang tersebut mampu dikelola dengan baik oleh pihak manajemen bank maka akan meningkatkan laba bank. Terdapatnya perbedaan hasil penelitian disebabkan oleh perbedaan lokasi penelitian dan perbedaan periode penelitian.

Hasil dari penelitian ini menunjukkan bahwa LAR berpengaruh positif signifikan terhadap ROA pada Bank Umum di BEI periode 2013-2015. Hal ini terlihat dari nilai koefisien regresi sebesar 0,415 dan nilai sig. thitung sebesar 0,049 lebih kecil dari 0,05 yang dapat diartikan bahwa ada pengaruh positif signifikan antara LAR terhadap ROA.

Hasil penelitian ini sejalan dengan penelitian yang dilakukan oleh Dewi et al. (2015), Anggraini (2014) dan Julita (2011) yang menyatakan bahwa LAR 
berpengaruh positif dan signifikan terhadap ROA. Semakin tinggi kredit yang diberikan bank, maka akan semakin besar kemungkinan pendapatan bunga yang diperoleh bank sehingga tingkat pengembalian asset (ROA) akan semakin tinggi.

Sebaliknya perbedaan penelitian yang dilakukan oleh Julaeha (2015) menyatakan bahwa LAR berpengaruh positif dan tidak signifikan terhadap ROA. Semakin besar kredit yang disalurkan tidak menjamin bahwa bank akan menghasilkan pendapatan bunga yang tinggi dan juga akan mengakibatkan tingkat pengembalian aset menurun. LAR yang bernilai positif dan tidak signifikan terhadap ROA, mengindikasikan bahwa besarnya pemberian kredit tidak didukung dengan kualitas kredit akan meningkatkan risiko terutama bila pemberian kredit dilakukan dengan tidak menggunakan prinsip kehati-hatian dan ekspansi dalam pemberian kredit yang kurang terkendali, sehingga bank akan menanggung risiko yang besar pula sehingga ROA akan menurun. Terdapatnya perbedaan hasil penelitian disebabkan oleh perbedaan lokasi penelitian dan perbedaan periode penelitian.

CAR adalah perbandingan modal bank dengan aktiva tertimbang menurut risiko. Hasil penelitian ini menunjukkan bahwa CAR berpengaruh positif signifikan terhadap ROA pada bank umum di BEI periode 2013-2015. Hasil penelitian ini mengindikasikan implikasi bahwa bank harus mampu menjaga modalnya agar tetap optimal, sehingga manajemen bank dapat menginvestasikan dananya pada aset yang menguntungkan yang nantinya dapat berpengaruh terhadap ROA bank.

NPL merupakan persentase jumlah kredit yang bermasalah terhadap total kredit yang diberikan bank. Hasil penelitian ini menunjukkan bahwa NPL berpengaruh negatif signifikan terhadap ROA pada bank umum di BEI periode 2013-2015. Hasil penelitian ini mengindikasikan implikasi bahwa manajemen bank harus memiliki kemampuan yang baik dalam penilaian kredit, penilaian atas jaminan dan pemantauan terhadap debitur, sehingga memungkinkan bank akan terhindar dari penumpukan kredit macet yang nantinya dapat berpengaruh terhadap ROA bank atas bunga pinjaman yang dibayarkan oleh debitur.

DER yaitu perbandingan antara hutang dengan modal sendiri. Hasil penelitian ini menunjukkan bahwa DER berpengaruh negatif signifikan terhadap ROA pada bank umum di BEI periode 2013-2015. Hasil penelitian ini mengindikasikan bahwa bank sebaiknya dalam menjalankan kegiatan operasionalnya menggunakan utang yang lebih sedikit, sehingga semakin kecil risiko yang mungkin ditimbulkan dan nantinya dapat berpengaruh terhadap ROA.

LAR adalah perbandingan jumlah kredit yang disalurkan dengan jumlah aktiva yang dimiliki bank. Hasil penelitian ini menunjukkan bahwa LAR berpengaruh positif signifikan terhadap ROA pada bank umum di BEI periode 2013-2015. Hasil penelitian ini mengindikasikan bahwa bank menyalurkan kredit dalam jumlah besar sebaiknya didukung dengan kualitas kredit yang baik, menggunakan prinsip kehati-hatian dalam pemberian kredit sehingga kemungkinan risiko yang ditanggung bank dapat menurun dan kemungkinan pendapatan bunga yang diperoleh bank sehingga tingkat pengembalian asset (ROA) akan semakin tinggi. 


\section{SIMPULAN}

Capital Adequacy Ratio berpengaruh positif signifikan terhadap Return on Asset pada Bank Umum di BEI periode 2013-2015. Non Performing Loan berpengaruh negatif signifikan terhadap terhadap Return on Asset pada Bank Umum di BEI periode 2013-2015. Debt to Equity Ratio berpengaruh negatif signifikan terhadap Return on Asset pada Bank Umum di BEI periode 2013-2015. Loan to Asset Ratio berpengaruh positif signifikan terhadap Return on Asset pada Bank Umum di BEI periode 2013-2015.

Bagi peneliti selanjutnya diharapkan dapat meneliti variabel-variabel lain yang dapat berpengaruh terhadap Return on Asset diantaranya yang terdapat pada faktor internal yang tidak diikutsertakan dalam penelitian ini, serta menambah periode waktu penelitian

\section{REFERENSI}

Almazari, A. A. (2013). Capital Adequacy, Cost Income Ratio and the Performance of Saudi Banks. International Journal of Academic Research in Accounting, Finance and Management Sciences, 3(4), 284-293. https://doi.org/10.6007/IJARAFMS/v3-i4/21

Alshatti, A. S. (2015). The Effect of the Liquidity Management on Profitability in the Jordanian Commercial Banks. International Journal of Business and Management, 10(1), 62-71. https://doi.org/10.5539/ijbm.v10n1p62

Anggraini, M. (2014). Analisis Pengaruh Financing To Deposits Ratio (FDR) Dan Loan To Assets Ratio (LAR) Terhadap Profitabilitas Perbankan Syariah Di Indonesia (Studi Kasus Pada Bank Umum Syariah Periode 2009-2013). Skripsi. Sarjana Jurusan Manajemen Fakultas Ekonomi dan Bisnis Universitas Muhammadiyah Surakarta.

Barus, A. C., \& Leliani. (2013). Analisis Faktor-Faktor yang Mempengaruhi Return Saham pada Perusahaan Manufaktur yang Terdaftar di Bursa Efek Indonesia. Jurnal Wira Ekonomi Mikroskil, 3(2), 111-121. Retrieved from https://www.mikroskil.ac.id/ejurnal/index.php/jwem/article/view/199/122

Buchory, H. A. (2015). Capital, Operational Efficiency And Credit Risk In The Banking Intermediation. International Journal of Business, Economics and Law, 7(2), 57-63. https://doi.org/10.2991/iceb-15.2015.27

Dewi, N. K. V. C., Cipta, W., \& Kirya, I. K. (2015). Pengaruh LDR, LAR, DER dan CR Terhadap ROA. E-Journal Bisma Universitas Pendidikan Ganesha, $3(1), 1-10$.

Enekwe, Innocent, C., Agu, Ikechukwu, C., \& Nnagbogu, E. K. (2014). The Effect of Financial Leverage on Financial Performance: Evidence of Quoted Pharmaceutical Companies in Nigeria. IOSR Journal of Economics and Finance, 5(3), 17-25. https://doi.org/10.9790/5933-0531725

Eng, T. S. (2013). Pengaruh NIM, BOPO, LDR, NPL \& CAR terhadap ROA Bank Internasional dan Bank Nasional Go Public Periode 2007-2011. Jurnal 
Manajemen Bisnis Dan Publik, 1(3), 153-167.

Havidz, S. A. H., \& Setiawan, C. (2015). The Determinants of ROA (Return On Assets) of Full-Fledged Islamic Banks in Indonesia. Journal MIX, 5(1), 161175.

Julaeha, L. (2015). Pengaruh Non Performing Loan, Net Interest Margin, Biaya Operasional/Pendapatan Operasional, dan Loan to Deposit Ratio terhadap Profitabilitas Bank (Studi Kasus Bank Rakyat Indonesia, Tbk 2003-2014). Jurnal Ekonomi Dan Bisnis, 20(3), 202-206.

Julita, I. (2011). Pengaruh Likuiditas Terhadap Profitabilitas Pada Sektor Perbankan Yang Terdaftar Di Bursa Efek Indonesia tahun 2008-2010. Jurnal Kajian Manajemen Dan Wirausaha, 2(1), 1-9.

Kasmir. (2012). Manajemen Perbankan. Jakarta: Rajawali Pers.

Kazumi, T. H., Lestari, S., \& Najmudin. (2015). Analisis Pengaruh Likuiditas, Efisiensi Operasional, NPL, NIM dan DER terhadap Profitabilitas Bank Perkreditan Rakyat yang Terdaftar di OJK. Journal \& Proceeding FEB Universitas Jenderal Soedirman, 5(1), 1-15.

Lestari, S. M., \& Widyawati, N. (2014). Faktor-faktor yang Mempengaruhi Return On Asset pada Perusahaan Perbankan di BEI. Jurnal Ilmu \& Riset Manajemen, $3(3), 1-22$.

Mawutor, J. K. M., \& Fred, A. (2015). Assessment of Efficiency and Profitability of Listed Banks in Ghana. Accounting and Finance Research, 4(1), 164-171. https://doi.org/10.5430/afr.v4n1p164

Mekonnen, Y. (2015). Determinants of Capital Adequacy of Ethiopia Commercial Banks. European Scientific Journal, 11(25), 315-331.

Olalekan, A., \& Adeyinka, S. (2013). Capital Adequacy and Bank's Profitability: An Empirical Evidence from Nigeria. American International Journal of Contemporary Research, 3(10), 87-93.

Prasanjaya, A. . Y., \& Ramantha, I. W. (2013). Analisis Pengaruh Rasio CAR, BOPO, LDR, dan Ukuran Perusahaan terhadap Profitabilitas Bank yang Terdaftar di BEI. E- Jurnal Akuntansi Universitas Udayana, 4(1), 230-245. https://doi.org/10.1016/j.jemermed.2010.11.035

Riyadi, S. (2006). Banking Assets and Liability Management. Jakarta: Lembaga Penerbit Fakultas Ekonomi Universitas Indonesia.

Sheefeni, J. P. S. (2015). The Impact of Bank Specific Determinants of Nonperforming Loans in Namibia. International Review in Emerging Markets and the Global Economy (IRREM), 1(5), 612-632. https://doi.org/10.5901/ajis.2015.v4n3s1p534

Sukarno, K. W., \& Syaichu, M. (2006). Analisis Faktor-Faktor Yang Mempengaruhi Kinerja Bank Umum Di Indonesia. Jurnal Studi Manajemen 
\& Organisasi, 3(2), 46-58. $\quad$ Retrieved from http://ejournal.undip.ac.id/index.php/smo

Sunarto, N. (2013). Pengaruh Non Performing Loan terhadap Return on Asset Sektor Perbankan di Indonesia. Jurnal Inovasi Bisnis, 1(1), 87-97.

Syahyunan. (2002). Analisis Kualitas Aktiva Produktif sebagai Salah Satu Alat Ukur Kesehatan Bank. Sumatera Utara: USU Digital Library.

Ulzanah, A. A., \& Murtaqi, I. (2015). The Impact of Earnings Per Share, Debt To Equity Ratio, and Current Ratio Towards the Profitability of Companies Listed in Lq45 From 2009 To 2013. Journal of Business and Management, 4(1), 1827. Retrieved from http://journal.sbm.itb.ac.id/index.php/jbm/article/viewFile/1384/820

Walsh, C. (2004). Key Management Ratios: Master The Management Metrics That Drive and Control Your Bussiness. Jakarta: Erlangga.

Wibowo, E. S. (2012). Analisis Pengaruh Suku Bunga, Inflasi, Car, Bopo, Npf Terhadap Profitabilitas Bank Syariah. Diponegoro Journal of Management, 10(6). https://doi.org/http://hdl.handle.net/10986/22167

Widati, L. W. (2012). Analisis Pengaruh CAMEL Terhadap Kinerja Perusahaan Perbankan Yang Go Publik. Dinamika Akuntansi Keuangan Dan Perbankan, 1(2), 105-119. Retrieved from http://www.unisbank.ac.id/ojs/index.php/fe9/article/view/1590 